\title{
Research on Enterprise Internationalization Strategy Based on Path Dependence Theory: Literature Review and Future Prospect
}

\author{
Weiwei Yang \\ School of Business Administration, South China University of Technology, Guangzhou, China \\ Email: 3065628736@qq.com
}

How to cite this paper: Yang, W.W. (2017) Research on Enterprise Internationalization Strategy Based on Path Dependence Theory: Literature Review and Future Prospect. American Journal of Industrial and Business Management, 7, 1229-1243.

https://doi.org/10.4236/ajibm.2017.711087

Received: October 31, 2017

Accepted: November 21, 2017

Published: November 24, 2017

Copyright $\odot 2017$ by author and Scientific Research Publishing Inc. This work is licensed under the Creative Commons Attribution International License (CC BY 4.0).

http://creativecommons.org/licenses/by/4.0/

\begin{abstract}
Although there are many kinds of literature on the internationalization of enterprises and strategic path dependence research were reviewed, there are no scholars on the path dependence theory perspective of the enterprise international strategy research specifically reviewed. In this paper, the literature review method is used to review the literature on the international strategic path of enterprises. First of all, the focus of combing the relevant literature involved in the concept, characteristics, the origin and development of the theory. Then, this paper introduces some scholars' related discussions on the internationalization path dependence of enterprises. Finally, on the basis of these, the future direction of the research on the path dependence of the internationalization of enterprises is put forward from the aspects of cognitive perspective, dynamic capability theory and theoretical framework.
\end{abstract}

\section{Keywords}

Enterprise Internationalization Strategy, Path Dependence, Literature Review, Future Prospect

\section{Introduction}

With the economic globalization and the continuous expansion of international competition in the Chinese government, "the Belt and Road" inspired by more and more Chinese private enterprises to join the international development of the ranks of China's private enterprises in international practice depth. Ghoshal (1987) [1], the classic discussion on globalization strategy from the dilemma faced by the internationalization of enterprises emphasizes the problem of international localization and global standardization, and makes an accurate defi- 
nition of the multinational strategy, the Transnational strategy and the globalization strategy. Since then, the importance of the strategy of globalization has become increasingly important, but Rugman A.M. \& verbeke A. (2008) [2] believes that there are few truly globalized enterprises, or that there are few companies that strictly enforce global standardization, due to the domestic macro-environment and the international market there is a big difference [3] [4], the real "globalization" of the enterprise is very small, and even the real implementation of the globalization strategy of private enterprises is also very little [5] [6]. The main reasons are the following two aspects: on the one hand, the development history of China's private enterprises is short, the practice of internationalization or globalization is not rich enough [5]. On the other hand, China's special market environment restricts the global strategic thinking of private enterprises.

Michael Porter pointed out that [7] [8] the advantage of the home country is the key to the success of the internationalization of enterprises, with particular emphasis on the specific advantages of the country on the international competitiveness of enterprises to build the role. China's global aspirations of the private sector is the industry's leading enterprises, these enterprises have a leading market share in the country, advanced technology and more professionals, these enterprises in the development of the domestic market, the formation and accumulation of competition advantages, core strategies and other experience and ability, is a huge and difficult to let go of the valuable wealth [9]. China's private enterprises in the international strategy are bound to be based on its accumulated in China's rich practical experience and consistent style in the global market, give full play to its advantages in the formation of the home country [10] [11]. For enterprises, the implementation of the international strategy is not its products or services simply enter the international market, internationalization means that the business strategy and management system in an all-round international standards [12] [13]. However, unlike the developed countries, the complex environment and the post-development of the transitional economy of the Chinese private enterprises have led to the study of the path dependence of the domestic core strategies and the internationalization strategies formed by the scholars in the home country environment.

\section{Research on Enterprise Internationalization: Strategic Management Perspective}

At present, scholars at home and abroad have made different definition and cognition on the concept of internationalization strategy based on different theoretical perspectives and starting points, generally speaking, the viewpoints in the field of economics, the viewpoints of behavioral science theory and the viewpoints of strategic management, only introduces the internationalization research in the field of strategic management.

The strategic management school developed in the 1950s and 1960s explored 
the internationalization of enterprises and the behavior of multinational corporations from the perspective of the environment, strategy and organizational adaptation, and studied how multinational corporations could establish a coherent competitive strategy. In the 1990s, the Resource-Based view explained the internationalization of the enterprise and became a common theoretical tool for analyzing the strategy and operation mode of multinational corporations. After entering the 21st century, some scholars put forward the Institutional-Based View, multinational enterprises in which the institutional environment also determines the enterprise's strategy and performance, the institution has an important influence on the choice of enterprise internationalization strategy

\subsection{Organization Theory of Enterprise Internationalization}

The organizational theory of corporate internationalization originated from Chandler (1962) [14], focusing on the relationship between corporate strategy and organizational structure, and explores the evolution of the organizational structure of internationalized enterprises. Chandler proposed the concept of structural follow-up strategy by exploring the evolution of the organizational structure of the four enterprises, and explored the relationship between business, environment, organizational structure and business performance. Subsequently, Stopford and Wells (1972) [15] more explicitly introduced the classical strategic management thought into the research of enterprise internationalization, They argued that there is a close relationship between corporate strategy, organizational structure and controlling options, With the diversification of products and the increase of the proportion of overseas sales, the organizational structure of enterprise internationalization presents a regular phase change. White and Poynter (1989) also found that the organizational structure of the internationalization of enterprises will evolve with the internationalization of the corporate competitive strategy as a more complex international regional structure and international product structure [16]. The "phase model" of Stopford and Wells regarded the whole multinational company as the unit of analysis, only focused on analyzing the overall difference between TNCs, but not realizing the role and role played by the overseas subsidiaries of TNCs in the process of internationalization. Since the 1980s, scholars, represented by Hedlund (1994), have begun to study the vertical hierarchical relationship between parent companies and subsidiaries of TNCs, noting that such hierarchical relationships can lead to large and inflexible organizational structures of TNCs [17]. With the intensification of environmental change, overseas subsidiaries are becoming the creators of cutting-edge ideas, the undertaker of important research tasks and the active participants in the implementation of strategic planning, This leads to the organizational structure of multinational companies no longer centered on the parent company, but tends to flatten and network. Bartlett and Ghoshal (1998) argued that Enterprise international competition requires the mobilization of all its resources and capabilities to create global efficiency, local responsiveness and 
global learning capacity, so that enterprises must develop an integrated network structure [18].

\subsection{Contingency Theory of Enterprise Internationalization}

On the basis of organizational theory research, Porter (1986), Bartlett and Ghoshal (1986, 1989, 1991), Doz and Prahalad (1984, 1991), Ghoshal and Westney (1993) and others continue to analyze the relationship between organizational strategy, organizational structure or management model and the environment On the study, They emphasized that enterprise performance is the result of adapting to the Environment of Enterprise organization, the enterprise must establish the strategy that matches the environment and decide the appropriate organization structure to obtain the good performance. Porter (1986) based on the theory of value chain [7] [8], pointed out that the two most important determinants of multinational corporation strategy, the one is the international distribution of value-added activities; the second is the location configuration of value chain activities.

Unlike the two strategic variables proposed by Porter, Bartlett and Ghoshal (1989) proposed two key dimensions of coordination and integration between subsidiaries and the degree of adaptation of subsidiaries to all national environments, and accordingly divide the international business into three categories: global organizations, multinational organizations and transnational organizations [19]. Bartlett and Ghoshal also pointed out those transnational organizations are the best structure or strategy to win the competition in the pursuit of efficiency and sensitivity. Prahalad and Doz (1991) proposed the "integration-response" (I-R) research framework and model from the response of multinational corporations to the external environment, and explored the dynamic factors of global integration and the formation of local responses. Prahalad and Doz integrated a variety of factors into a framework to consider, integrating TNCs' strategies into local strategies, multiple-center strategies and integration strategies along the two dimensions of integration pressures and localized pressures [20].

\subsection{The Resource-Based View of Enterprise Internationalization}

From the 1990s to early 21st century, resource-based view began to be the focus of enterprise internationalization theory. According to the resource-based view, when the enterprise's resources and capabilities are unique, valuable, scarce and difficult to imitate, companies can get a long-term competitive advantage (Barney, 1991) [21], which is the core competitiveness of enterprises. Bartlett and Ghoshal (1989) [19] argue that the core competencies of enterprises are usually established in the home country and can be applied to the international market to further enhance the profits of the enterprise. Rugman and Verbeke (2008) [2] further point out that the specific resources of an enterprise can be generated anywhere in a multinational company, not necessarily from a parent company 
or a corporate headquarters, including location-bound and non-Geographical location (non-location-bound) two different types, according to the characteristics of different key resources, companies should choose a different international strategy.

Tallman and Li (1996) [22], Hitt, Hoskisson and Kim (1997) [23] also used the resource-based view to analyze the benefits of internationalization. Their research shows that in the process of internationalization, enterprises with unique internal capabilities are more profitable by integrating cross-border resources, earning the best economies of scale and allocating key investments. At the same time, internationalization makes it possible for companies to explore other untapped resources and offer unique opportunities to proactively create new resources. Geringer, Tallman and Olsen (2000) [24] think that when enterprises can make good use of resources and ability advantage in the international market, with the expansion of the international market, the performance of enterprises will also be promoted, thus forming a virtuous circle of resource accumulation, transnational use and enterprise performance improvement.

Hitt, Hoskisson, and Kim (1997) [23] have found that firms with unique internal capabilities are able to make greater profits through internationalization, but some scholars are aware that with the increase in overseas market differentiation, The complexity of the distributed business unit will multiply, and the complexity of such organization and the environment will eventually outweigh the degree of enterprise management Some scholars engaged in cross-cultural studies also pointed out that the geographical dispersion of business activities and cultural diversity will lead to communication, coordination and incentives and other issues and difficulties (Hofstede, 1980) [25]. Alvaro et al. (2007) further analyzed the reasons for the above costs or difficulties from the perspective of corporate resource perspectives, believing that firms cannot transfer their dominant resources abroad, that some resources are transferred to foreign countries and lose their original value, and even become an overseas business of the unfavorable factors or obstacles, the lack of overseas business supporting resources and so on is the cause of international business failure and performance reduction of the main reasons.

\subsection{The Institutional-Based View of Enterprise Internationalization}

The formation of institutional-based view is the result of deepening the understanding of the role of the institution in the strategic theory. The influence of "institution" on the enterprise strategy has been mentioned in the theoretical circle (Law Rence \& Lorsch, 1969) [26], but these studies are based on the developed countries, and only the institution as a known background condition for the strategic choice of enterprises. The early institutional theorists, represented by Scott, first analyzed the strategies under different systems from the organizational Level [27], followed by Mike W. Peng is a representative of the scholars from the institution, organization, strategic integration of the comprehensive 
study [28], the institutional-based view gradually formed. On the basis of summarizing the predecessors' theory, Mike W. Peng proposed two core propositions based on the institutional basis [29]. The first is the proposition of bounded rational choice, that is, "under the given institutional framework, managers and enterprises in the formal and informal constraints to rationally pursue their interests and make strategic choices", the second is the official And the informal system complementarity proposition that "when formal and informal systems influence corporate behavior together, where informal systems are unclear or ineffective, informal systems will, to a large extent, reduce uncertainty, provide guidance, and to provide returns to managers and businesses. "In 2000, Mike W. Peng in the study of the relevant research results, summed up the relationship between the institution, organization and strategic choice. There is a dynamic interaction between institutions and organizations, the institution affects the organization, and the organization has an impact on the institution. Mike W. Peng (2003) [30], taking the emerging economies of China, Poland and Russia as examples, the paper studies the strategic choice of enterprises in emerging economies in the face of institutional transformation, in his opinion, whether the enterprise is local or foreign, the dynamic change of the system transformation makes the enterprise's strategic choice inevitable change. In 2005 Klaus E. Meyer and Mike W. Peng have conducted research transactions, resources and institutions in Central and Eastern Europe. They pointed out that in the 1990s, economic development in Central and Eastern Europe promoted the development of organizational economic theory, theory and institutional theory, and they used these three kinds of theories to study several specific enterprise strategy choices, such as the entry strategy of foreign investors, local enterprises and Government's reorganization strategy and enterprise's entry and growth strategy [31].

The strategic theory of institutional-based view is more concerned with the institutional environment outside the emerging economies and organizations, and the micro-institution within the organization, such as the organization's management institution, management activities and practice, is often neglected in the process of research institution strategy. In emerging economies, formal systems in the text look like those of the West, but in reality informal norms and perceptions are more effective. The findings from emerging economies may not be generalized to the institutional context of other countries.

\section{Path Dependence: Origin and Development}

Since the 1980s, path dependence has become an important concept to understand the transnational development of enterprises. At present, the research on this content in academia is still continuing, so it is necessary to comb the path dependence theory, clarify the basic connotation of path dependence and its main theoretical contribution. In this paper, the background of path dependency research and the application of path dependence in technology change and sys- 
tem change are reviewed, and the running mechanism of path dependence is introduced to better understand the path dependence of enterprise strategy.

\subsection{The Origin of Path Dependence}

The concept of path dependence is derived from the field of natural sciences. Gould's view of the evolution of species is a significant feature of the fact that a species affects the future in a related way. He studies for the first time in the study of intermittent equilibrium in biological evolution. The concept of "path dependence", and further proposed the biological evolution path mechanism and the path of non-optimal choice of the problem [32]. David (1975) first incorporated the concept of "path dependence" into the category of economics in "Technology Choice, Innovation and Economic Growth", David and Arthur (1985) [33] explained the path dependence its concept to be defined, in-depth study of its operating mechanism; the path dependence will rise to the systematic level. North (1993) succeeded in explaining the evolution of the economic system with the "path dependence" theory [34].

Based on the research results of North's theory of institutional change, some scholars try to introduce the idea of path-dependence into corporate governance, which is more representative of the study of Bebchuk and Roe [35]. In their research on the firm, they found that while some companies were decentralized, managers were able to control the company firmly, while others, while concentrated in ownership, had a strong impact on the company. Bebchuk and Roe argue that the reason for this is that there is a significant path dependence in the pattern of a company's ownership structure [35]. In other words, because of path dependence, the ownership structure pattern of a country at any one point depends partly on its previous pattern. They divided the path dependence of corporate governance into structure-driven path dependencies and institutional-driven path dependencies. The structure-driven path depends on the direct impact of the initial ownership structure on the subsequent ownership structure, which is due to efficiency and rent-seeking.

Scholars believe that the emergence of path dependence process, usually attributed to the economic system of self-enhancement mechanism or income increase mechanism [36]. This kind of mechanism makes technology, system, strategy and so on once choosing a certain path, its direction will be strengthened unceasingly in the future development, difficult to change. The reason why the self enhancement mechanism will appear is the five aspects of scale economy, learning effect, cooperation effect, adaptability expectation and network externality.

As an important concept of organization, economy and management, path dependence has not yet been clearly defined. In 2000, Mahoney summed up the different scholars' knowledge of path dependence, there are three characteristics of their path dependence: First, path dependence is a study of causal process, which is very sensitive to the early stage of history, and the second is based on 
the viewpoint of path dependence, the early historical events are randomly occurring, This randomness cannot be explained by previous events or "initial states"; third, once the random historical events occur, path dependence has the relevant deterministic causal pattern or can be called "inertia". Although scholars have a different understanding of the concept of path dependence, there are some consensuses [37]. Mainly as follows:

1) Path dependence emphasizes the time factor in the institution transition, emphasizing the historical "lag" role. This "lagging" role is both likely to be the result of historical events, and possibly the nature of the history itself (intrinsic rules and order).

2) Path dependency is both a state and a process. In the process, path dependency is a non ergodic stochastic dynamic process, which is strictly dependent on historical accidental events (small probability events); In terms of state, path dependency is a "lock" that can be either efficient or inefficient.

To sum up, path dependence does not necessarily mean historical determinism or "past dependence". Instead, path dependence is a random, situational process, at every point in history, the possible future evolution of technology, institution, enterprise and industry is determined by history and current state. The state of the past sets the possibility, and the current state controls which possibilities can be explored, which can only be explained later. The definition of path dependence can be summarized as Table 1 .

\subsection{Path-Dependent Operation Mechanism}

Path dependency cycles can be summed up four links as follows [38]: given conditions, launch mechanisms, formation, Out of lock:

1) Given the condition, refers to the occurrence of random events, which start and decided to route the external contingency event occur.

2) Launch mechanisms: refers to the process of increasing return mechanism. It started with the establishment of given conditions, usually with four performances, including initial setup costs, learning effects and coordinated effects and adaptive expectations.

3) Formation: refers to mechanisms of increasing returns to run the system a certain State or results, once a "self-reinforcing mechanism" started under the influence of contingency factors, will appear the following characteristics of the system:

a) Multiple equilibri, the result of the evolution of the system is not a single, but there is a wide selection of programmes.

b) Lock, that is once the contingency factor for a particular program was adopted, increasing return mechanism will prevent it from interference by external elements, or be replaced by other programmes [39].

c) Possible non-optimal path, due to increasing returns and other factors prevent people from the use of other programmes to develop awareness and dynamic, so that the programmes may not necessarily be optimal in locked state. 
Table 1. Some explanations of the path dependence concepts.

\begin{tabular}{|c|c|c|}
\hline Scholar & Definition & Related concepts \\
\hline $\begin{array}{l}\text { David } \\
(1985)\end{array}$ & $\begin{array}{l}\text { The order of path-dependent economic transformations is this: the consequences of a } \\
\text { significant impact on the final outcome can be caused by events that are far away from time, } \\
\text { including accidental events caused by accidental rather than systematic forces. A random } \\
\text { process like this does not necessarily automatically converge to the result of a fixed-point } \\
\text { dispersion, a process called non ergodic. }\end{array}$ & $\begin{array}{l}\text { Accidental events } \\
\text { Non-ergodicity }\end{array}$ \\
\hline $\begin{array}{l}\text { Arthur } \\
(1989)\end{array}$ & $\begin{array}{l}\text { Under the positive feedback mechanism, the increasing result leads to the preference of a } \\
\text { particular technology and the dominant position. }\end{array}$ & Increased returns \\
\hline $\begin{array}{l}\text { Liebowitz, } \\
\text { Margolis } \\
(1995)\end{array}$ & $\begin{array}{l}\text { Path dependency refers to a small or inconspicuous advantage or a seemingly technical, } \\
\text { product or standard irrelevant matters may have an important and irreversible effect on the } \\
\text { ultimate resource allocation market, even if the real world is composed of individuals with } \\
\text { autonomous decisions and individual interests maximizing behavior. }\end{array}$ & $\begin{array}{l}\text { Tiny event } \\
\text { Irreversible }\end{array}$ \\
\hline $\begin{array}{l}\text { Sewell } \\
(1996)\end{array}$ & $\begin{array}{l}\text { Path dependency is what happened earlier to have an impact on the possible outcome of } \\
\text { subsequent events. }\end{array}$ & $\begin{array}{l}\text { The role of historical } \\
\text { development }\end{array}$ \\
\hline $\begin{array}{l}\text { Pierson } \\
(2000)\end{array}$ & A path-dependent history or time process characterized by a self-reinforcing event order. & Self-reinforcing \\
\hline $\begin{array}{l}\text { Schmidt, } \\
\text { Spindler (2002) }\end{array}$ & Path dependence is caused by the conversion cost and evolving myopia & $\begin{array}{l}\text { Conversion cost Evolving } \\
\text { myopia }\end{array}$ \\
\hline $\begin{array}{l}\text { Sydow } \\
(2005)\end{array}$ & $\begin{array}{l}\text { Path dependence is a continuous process, in the positive feedback mechanism, due to } \\
\text { accidental factors or personal preferences and local search to enter the positive feedback, } \\
\text { self-improvement stage. }\end{array}$ & $\begin{array}{l}\text { Positive feedback } \\
\text { Lock-in }\end{array}$ \\
\hline $\begin{array}{l}\text { Ebbinghaus } \\
(2005)\end{array}$ & $\begin{array}{l}\text { There are two kinds of path dependence: one is the unplanned "country road", is randomly } \\
\text { selected by the people and later repeated, naturally formed the road; the other is the "road } \\
\text { jungle" in each fork Point must choose one to continue to move forward. }\end{array}$ & Random selection \\
\hline
\end{tabular}

Source: Author finishing.

d) Path dependence, that path system evolution depends on the initial state of the system. The initial state is very sensitive to contingency events, once the system before and after the adoption of a program; the evolution path of the system will be rendered coherent, interdependent characteristics.

4) Out of lock, refer to external forces such as through government intervention, and path instead.

Sustainable competitive advantages of enterprises formed in the home country, especially those that have sustainable competitive advantage transferability, adaptations in the international market through the formation of an international strategy, which determines the international strategy to some extent with path-dependent features. Path Dependence enterprise internationalization strategy mainly from strategic thinking, strategic behavior and path core competitiveness depend on three factors. Enterprises in the target market selection, international market entry mode choice of a certain degree of bias, develop core competitiveness. There are many different paths and different paths with different performance. Enterprises in the choice of target market, the choice of international market access to a certain degree of bias, the development of core competitiveness has many different paths, and different paths have different performance [40]. The initial contingency selection will evolve into the core competi- 
tiveness of a particular path, regardless of the performance of the path; the path will be formed dependent.

\section{Discussion on the Path Dependence of Enterprises Internationalization}

Domestic and foreign scholars have made some research on the internationalization strategy or path dependence, and have analyzed the application to a certain extent and put forward many opinions and opinions. However, there are few studies on the path dependence in strategic management, and the theoretical system and research methods have not yet been formed. At present, there is not a lot of research on the relationship between strategy and path dependence.

Sun Xue-min (2004) [41] that the growth of enterprises is a simple expansion of the scale of the process of complex adjustment, it is a variety of relationships within and outside the balance of adjustment for the substantive characteristics of seeking from the balance to the balance, from the lower Balance to a high level of balanced balance of development process. Grasp the growth of enterprises; help to identify the path of business growth, so as to guide enterprises to develop a growth strategy.

The impact of the growth path of the strategic choice of enterprises, especially the path dependence in the process of enterprise growth, is also an important factor in the study of corporate strategic behavior in enterprise strategic management. Evolutionary economist Nelson \& Winter (1982), Edith Penrose (1959, 1995), Leonard-Barton (1992), economist at the theory of enterprise competence theory, have studied the path dependence in the process of enterprise development. The path dependence in the development of enterprises is the self-duplication or genetic mechanism formed in the enterprise evolution, which has important influence on the future strategic choice of the enterprise.

Nelson and Winter (1982), in their book THE EVOLUTIONARY THEORY OF ECONOMIC CHANGE [42], used a routine to illustrate path dependencies. In constant or cyclical repetitive static "circular flow" environment, the enterprise's individual members and the entire organization face the situation is identical or similar, the enterprise organization is only practices, because these practices represent the enterprise in the past successfully to cope with the environmental change, obtains the valuable experience which the satisfactory return. But when the environment becomes more dynamic and more complex, the enterprise can also follow the path dependence and make the same strategic choice to reduce risk and uncertainty. Nelson and Winter (1982) [42] believe that the practice followed by the enterprise is inert for environmental change, and another reason is that "the practice involves a complete truce of internal conflict within the organization", Because the internal practice of the enterprise is in the interaction between the enterprise members and the enterprise and the external environment evolved.

The path dependence in the process of enterprise growth can be manifested through three aspects: the inertia of entrepreneur behavior, the strong depen- 
dence of enterprise on a special resource and ability, the continuity of enterprise culture and enterprise value concept. These three reasons will cause enterprises to avoid risk and repeat their strategic choice behavior, that is, the path dependence in the strategic selection process. It is difficult for enterprises to rely on industry diversification to take the initiative to return to the main business; it is difficult to rely on successful companies to focus strategic choices on building and developing core expertise [43].

The study of historical strategy by Mintzberg also points out that strategic behavior is path-dependent, that is, the process's own history creates a specific trajectory that limits strategic decisions. In strategic management, path dependence often means that an enterprise's previous investment and its institutional library constrain its future behavior (Teece et al., 1997) [44]. The path dependence in the strategy can, therefore, be considered a trend of "continuing to do the same thing" or because they have the ability or knowledge to accomplish a particular task, or because they cannot escape from their history (Maskell \& Malmberg, 2007) [45] also points out that the strategy will be influenced by past practice (path) in the course of its implementation, and even through intelligent, self-interested individuals to achieve conscious knowledge creation, it will eventually become path dependent, because today's practice is related to yesterday's learning practices and knowledge (Maskell \& Malmberg, 2007) [45], Mason RB (2007) [46] argues that corporate internationalization must follow the path dependence theory and, in particular, Management tradition.

Although there is not much research on the relationship between strategy and path dependence, some strategic and path dependence can still be found in the literature of strategic management. The strategic choice school, represented by Child, argues that the company's strategy is the result of a subjective decision that the company's top executives can consciously change the company's track of development [47]. The school, which is represented by the Carnegie school, insists on emphasizing the cognitive limitations of individual decision makers, making decisions based on rules as actors, and making decisions that attempt to change trajectories is very complex. "Staying on an existing path or discovering and creating a new path" is an eternal topic that organizational managers need to face. Therefore, the relationship between strategic choice and management cognition in strategic management can also be extended to the topic of path dependence and path creation. In the process of enterprise evolution, path dependence is a positive factor or a negative factor, how to achieve the transformation of the strategic path and how to maintain a moderate path dependence and moderate path creation in corporate strategic behavior. These problems need to be path dependent. The further study of the study and the re-excavation and understanding of the theory of strategic management can be answered.

\section{Conclusions and Discussion}

This paper through the literature combing, discovered that although the enter- 
prise internationalization strategy and the path dependence theory research has appeared the massive achievement respectively, the path dependence theory system which can apply in the enterprise internationalization strategy is still not formed; the enterprise internationalization path formation and the development in many questions are also needed to be discussed further. Through the excavation and analysis of existing literatures, this paper I hope to contribute to the following aspects, firstly, we hope to promote the construction of the strategic path dependence theory system for the internationalization of enterprises, and make theoretical contribution to the international business research, and provide theoretical guidance for the development of the enterprise internationalization strategy. Secondly, we hope to contribute to the theory of path dependence, although many new achievements and new features have been made by the theory of path dependence, the theory system of path dependence is still not formed, and this article hopes to make as much contribution as possible. Thirdly, we hope to contribute to the strategic management of enterprises, especially the theoretical research in the field of enterprise internationalization. It provides the direction for exploring the influence mechanism of enterprise internationalization strategy. At the same time, in order to further promote the development of this research field, this paper puts forward some thoughts and inspirations in the future research direction, hoping to provide the research direction for the relevant research scholars:

First, there are different perspectives on the knowledge of internationalization strategic path dependence. In fact, path dependence exists at different levels, such as institutional level, technical level and organizational level. In the research and application of the internationalization strategic path dependence, we need to grasp the analysis unit.

Second, the understanding of the essence of internationalization strategic path depends on a dynamic and evolutionary view. The internationalization strategy path dependence is not a final state result, but an evolutionary process. The factors which lead to the enhancement of path dependence in the process of internationalization strategy path dependence may also be the factors that lead to the final breakthrough path dependence, and the analysis of the internationalization strategy path dependence and the corresponding realization path transformation should stick to a common evolution viewpoint.

Third, the research of strategic path dependence theory needs a whole theoretical framework. In view of the numerous viewpoints existing in the research of path dependence, in order to avoid the confusion caused by theoretical dispersion and lack of explanatory power, it is necessary to try to integrate the existing research to provide clear ideas for solving and evading realistic problems under the guidance of a holistic theoretical framework.

Although the concept of strategic path dependence has been put forward for many years, scholars from different fields have carried out extensive research on it from their respective perspectives, and the domestic research on strategic path 
dependence is still in the exploratory stage, focusing on the general application of the concept and the lack of thorough and meticulous exploration. By combing through the literature, it is hoped that scholars' interest in path dependence and related theoretical research can be combined with the practical needs of social and economic development in China's transitional period, from the aspects of organization, management, technology, economy and social system, such as the internationalization strategy of Chinese private enterprises, cross-cultural management, the degree of internationalization, research on key issues such as strategic control.

\section{References}

[1] Ghoshal, S. (1987) Global Strategy: An Organizing Framework. Strategic Management Journal, 8, 425-440. https://doi.org/10.1002/smj.4250080503

[2] Rugman, A.M. and Verbeke, A. (2008) The Theory and Practice of Regional Strategy: A Response to Osegowitsch and Sammartino. Journal of International Business Studies, 39, 326-332. https://doi.org/10.1057/palgrave.jibs.8400349

[3] Arregle, J.L., Miller, T.L., Hitt, M.A. and Beamish, P.W. (2013) Do regions matter? An integrated institutional and Semiglobalization Perspective on the Internationalization of Mnes. Strategic Management Journal, 34, 910-934. https://doi.org/10.1002/smj.2051

[4] Boisot, M. and Meyer, M.W. (2008) Which Way through the Open Door? Reflections on the Internationalization of Chinese Firms. Management \& Organization Review, 4, 349-365. https://doi.org/10.1111/j.1740-8784.2008.00116.x

[5] Wu, C.Q. (2010) Strategic Management Research in China: Past, Present and Future. Nankai Business Review, 13, 25-40.

[6] Luo, Y. and Tung, R.L. (2007) International Expansion of Emerging Market Enterprises: A Springboard Perspective. Journal of International Business Studies, 38, 481-498. https://doi.org/10.1057/palgrave.jibs.8400275

[7] Porter, M. (2005) Competitive Strategy. Hua Xia Publishing Co., Ltd., Beijing.

[8] Porter, M. (2005) The Competitive Advantage of Nations. Hua Xia Publishing Co. Ltd., Beijing.

[9] Bing, H. (2004) The Path Dependence of Chinese Corporate Governance -Theoretical and Positive Analysis. Engineering Science, 2, 82-87.

[10] Zhao, S., Gao, S., Zhou, J. and Liu, J. (2010) An Analysis on the Condition, Path and Mode of Corporations' Internationalization and Its Inspirations. Science of Science \& Management of $S \& T, 5,115-150$.

[11] Liu, L., Han, F. and Mei, S. (2016) The Catching-Up Strategies of Emerging Market Firms: A Literature review. Science \& Technology Progress \& Policy, 14, 155-159.

[12] Yip, G.S. (1989) Global Strategy: In a World of Nations? Sloan Management Review, 31, 29-41.

[13] Yip, G.S., Loewe, P.M. and Yoshino, M.Y. (1988) How to Take Your Company to the Global Market. Columbia. Journal of World Business, 23, 37-48.

[14] Chandler, A.D. (1962) Strategy and Structure: Chapters in the History of the American Industrial Enterprise. MIT Press, New York.

[15] Stopford, J. and Wells, L.T. (1972) Managing Multi-National Enterprise. Basic Books, New York. 
[16] White, R.E. and Poynter, T.A. (1989) Organizing for Word-Wide Advantage. Business Quarterly, 54, 84-89.

[17] Hedlund, G. (1994) A Model of Knowledge Management and the n-Form Corporation. Strategic Management Journal, 15, 73-90. https://doi.org/10.1002/smj.4250151006

[18] Bartlett, C.A. and Ghoshal, S. (1998) Managing across Borders: The Trans-National Solution. Harvard Business School Press, Boston.

[19] Bartlett, C.A. and Ghoshal, S. (1989) Managing across Borders: The Trans-National Solution. Harvard Business School Press, Boston.

[20] Doz, Y.L. and Prahalad, C.K. (1991) Managing DMNCS: A Search for a New Paradigm. Strategic Management Journal, 12, 145-164. https://doi.org/10.1002/smj.4250120911

[21] Barney, J.B. (1991) Firm Resources and Sustained Competitive Advantage. Journal of Management, 17, 99-120. https://doi.org/10.1177/014920639101700108

[22] Tallman, S. and Li, J. (1996) Effects of International Diversity and Product Diversity on the Performance of Multinational Firms. Academy of Management Journal, 39, 179-196. https://doi.org/10.2307/256635

[23] Hitt, M.A., Hoskisson, R.E. and Kim, H. (1997) International Diversification: Effects on Innovation and Firm Performance in Product-Diversified Firms. Academy of Management Journal, 40, 767-798. https://doi.org/10.2307/256948

[24] Geringer, J.M., Tallman, S. and Olsen, D.M. (2000) Product and International Diversification among Japanese Multinational Firms. Strategic Management Journal, 21, 51-80. https://doi.org/10.1002/(SICI)1097-0266(200001)21:1<51::AID-SMJ77>3.0.CO;2-K

[25] Hofstede, G.H. (1980) Culture's Consequences: International Differences in Work-Related Values. Sage Publications, Beverly Hills.

[26] Lawrence, P.R. and Lorsch, J.W. (2007) Organization and Environment: Managing Differentiation and Integration. Pickering \& Chatto.

[27] Scott, W.R. (2001) Institutions and Organizations. Sage Publications.

[28] Peng, M.W. (2000) Business Strategies in Transition Economies.

[29] Peng, M.W. and Chen, H. (2009) The Institution-Based View as a Third Leg for a Strategy Tripod. Academy of Management Perspectives, 23, 63-81.

https://doi.org/10.5465/AMP.2009.43479264

[30] Peng, M.W. (2003) Institutional Transitions and Strategic Choices. Academy of Management Review, 28, 275-296.

[31] Meyer, K.E. and Peng, M.W. (2005) Probing Theoretically into Central and Eastern Europe: Transactions, Resources, and Institutions. Journal of International Business Studies, 36, 600-621. https://doi.org/10.1057/palgrave.jibs.8400167

[32] Cao, X., Xi, Y. and Chen, X. (2008) Reviewing Studies on Path Dependence. Comparative Economic \& Social Systems, 3, 185-191.

[33] David, P.A. (1985) Clio and the Economics of Qwerty. American Economic Review, 75, 332-337.

[34] Douglas, C.N. (2008) Institutional, Institutional Change and Economic Performance. Shanghai People's Publishing House, Shanghai.

[35] Bebchuk, L.A. and Roe, M.J. (1999) A Theory of Path Dependence in Corporate Ownership and Governance. Stanford Law Review, 52, 127-170. https://doi.org/10.2307/1229459 
[36] Li, H. and Lin, Z. (2012) Mechanism of Path Dependence and Path Creation in Organizational Structure Change: The Case of Lenovo Group. Chinese Journal of Management, 9, 1135-1147.

[37] Mahoney, J. (2000) Path Dependence in Historical Sociology. Theory \& Society, 29, 507-548. https://doi.org/10.1023/A:1007113830879

[38] Liu, Y. (1999) On Framework of Path-Dependent Analysis. Teaching and Research, 1, 43-49.

[39] Martin, R. and Sunley, P. (2006) Path Dependence and Regional Economic Evolution. Papers in Evolutionary. Economic Geography, 6, 395-437. https://doi.org/10.1093/jeg/lbl012

[40] Garrouste, P. and Ioannides, Z. (2001) Evolution and Path Dependence in Economic Ideas.

[41] Sun, X. (2004) The Growth Essence and Ways of the Middle and Small Enterprises. Journal of Zhengzhou University, 4, 66-69.

[42] Nelson, R. and Winter, S. (1982) The Evolution Theory of Economic Change. The Commercial Press, Chinese Version in 1997, Beijing.

[43] Yang, Q. and Liu, S. (2003) Analysis on Objective Conditions of Chinese Multinational Company Growth. China Soft Science, 9, 80-83.

[44] Teece, D.J., Pisano, G. and Shuen, A. (1997) Dynamic Capabilities and Strategic Management. Strategic Management Journal, 18, 509-533. https://doi.org/10.1002/(SICI)1097-0266(199708)18:7<509::AID-SMJ882>3.0.CO;2$\underline{Z}$

[45] Maskell, P. and Malmberg, A. (2007) Myopia, Knowledge Development and Cluster Evolution. Social Science Electronic Publishing, 7, 603-618.

https://doi.org/10.1093/jeg/lbm020

[46] Mason, R.B. (2007) The External Environment's Effect on Management and Strategy: A Complexity Theory Approach. Management Decision, 45, 10-28. https://doi.org/10.1108/00251740710718935

[47] Child, J. and Rodrigues, S.B. (2005) The Internationalization of Chinese Firms: A Case for Theoretical Extension? Management \& Organization Review, 1, 381-410. https://doi.org/10.1111/j.1740-8784.2005.0020a.x 